\title{
Apología de la polémica como modalidad argumentativa: el conflicto público en Brasil en las protestas de 2015
}

\author{
Apology of Polemics as an Argumentative Modality: \\ Public Conflict in 2015 Brazil Demonstrations
}

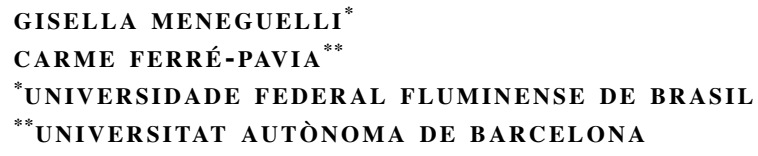

Artículo recibido el / Article received: 28-10-2015 Artículo aceptado el / Article accepted: 09-10-2016

RESUMEN: Esta investigación analiza las protestas ciudadanas que ocurrieron en Brasil en marzo de 2015, teniendo en cuenta la construcción discursiva de la polémica política en la generación de confrontación pública. El análisis propuesto se basa en los conceptos de dissensus y polémica siguiendo a Amossy, para diseccionar 20 carteles elaborados por ciudadanos brasileños que salieron a las calles para exigir el impeachment de la actual presidenta, Dilma Rousseff. Para dar cuenta de la diversidad de los temas de los carteles, consideramos categorías basadas en los estudios sobre construcción de la imagen de los sujetos de discurso (Amossy, 2014; Charaudeau, 2013a, 2013b) y polémica (Amossy, 2014). Las protestas mostraron una paradoja entre el derecho a la manifestación pública y la reclamación del regreso de una dictadura militar. Las conclusiones abordan el límite argumentativo de la polémica y de la violencia verbal como medios para valorar o denostar el estado de la democracia en Brasil. La destitución de Roussef en 2016 contextualiza en el tiempo los efectos de estos discursos.

Palabras clave: análisis del discurso, argumentación, conflicto, Dilma Rousseff, impeachement, manifestaciones.

ABSTRACT: This research analyzes the civic demonstrations that occurred in March 2015 in Brazil, with a perspective of political debate and conflict discursive construction. The study proposed focuses on the concepts of dissensus and polemics following Amossy theories. 20 posters made by citizens and showed 
during Rousseff's impeachment protests have been analyzed. Different topics have been selected, adapting the categories of subject of discourse image construction (Amossy, 2014; Charaudeau, 2013a, 2013b) and polemics (Amossy, 2014). Demonstrations generated a paradox between the right to protest and the defense of a military dictatorship. Conclusions approach to the argumentative limits of polemics and verbal violence as tools to value or attack the state of democracy in Brazil. Rousseff's 2016 impeachment gives a more complete context to those discourses effects.

Keywords: argumentation, conflict, demonstrations, Dilma Rousseff, discourse analysis, impeachment.

\section{INTRODUCCIÓN}

En mayo de 2016 se culminó en Brasil el proceso de impeachment contra la presidenta Dilma Roussef. El ambiente de crispación social y polarización partidista se plasma en las manifestaciones públicas, que no eran las primeras de este proceso político. En marzo de 2015 ocurrieron varias protestas en diferentes ciudades de Brasil, sobre todo en las más urbanizadas, motivadas por la corrupción de la clase política. El objetivo de las manifestaciones fue, principalmente, el partido que se encontraba en el gobierno hacía más de una década y una de las exigencias de los concentrados fue el impeachment de la entonces presidenta, Dilma Rousseff.

El segundo gobierno de Dilma Rousseff empezó con una gran crisis económica, con el dólar y la inflación muy altos, lo que intensificó la presión popular por su salida del gobierno. El escándalo de corrupción de mil millones de dólares en Petrobrás provocó más descontento popular y algunos medios de comunicación y la oposición política vincularon la presidenta al desvío de dinero en la empresa petrolera. Todo ese escenario desfavorable a Rousseff articuló las protestas que pedían su impeachment. Es importante decir que el impeachment es un proceso jurídico que debe pasar por un debido proceso legal.

Es interesante observar que la manifestación de 2015 estuvo orientada ideológicamente por la derecha, que en cambio se opuso a las protestas que empezaron en $2013^{1}$ y tuvieron eco en 2014 durante la celebración del Mundial

1. Las protestas de 2013 empezaron con una orientación social de izquierda, en varias ciudades de Brasil, con la exigencia de mejora en el sistema de transporte público. La pauta creció apelando a otros derechos sociales. 
de Fútbol, tanto ante algunos temas coincidentes como en el diferente perfil de los manifestantes.

Ante ese escenario, esta investigación analiza las protestas ciudadanas que ocurrieron en Brasil en marzo de 2015 partiendo de la construcción discursiva de la polémica política en la generación de confrontación pública. El concepto de dissensus (Amossy, 2014) aparece como el motor que hace avanzar la democracia, y el de polémica, como la modalidad argumentativa que estructura el discurso orientado al conflicto para lograr cambios sociales.

Analizamos 20 carteles elaborados por ciudadanos brasileños que fueron invitados, a través de las redes sociales, a ir a las calles para exigir el impeachment de la expresidenta, Dilma Rousseff, como manera de simbolizar el agotamiento del pueblo con la corrupción en Brasil. En los carteles que desfilaron en las protestas en varias ciudades del país, se observó una diversidad de reclamaciones que no solo exigían el impeachment, sino que ponían en juego la democracia. Las protestas dieron muestra de una paradoja entre el derecho a la manifestación pública y el deseo de regreso de una dictadura.

\section{MARCO TEÓRICO CONCEPTUAL}

\subsection{La situación de comunicación}

Hay una gran confusión respecto al concepto de la situación de comunicación, que muchas veces se confunde con otro concepto, el del contexto. Por eso, es necesario delimitar que son uno y otro. La situación se refiere al ambiente físico-social del acto de lenguaje y el contexto se refiere al ambiente textual de la palabra. Luego, este es interno al acto de lenguaje, mientras que aquella es externa a él, aunque constituya sus condiciones de producción.

De una manera general, la situación de comunicación se refiere al conjunto de condiciones que organizan la emisión de un acto de lenguaje (Chaureaudeau \& Maingueneau, 2013) y que nos permite interpretar un enunciado si conocemos un cierto número de datos que funcionan como instrucciones situacionales.

Desde un punto de vista discursivo, eso significa que todo acto de lenguaje se realiza en una situación de comunicación normatizada, o rutinizada, que está compuesta por la expectativa de cambios y por la presencia de las restricciones de la escenificación del discurso.

La situación de comunicación define la posición de legitimidad de los sujetos hablantes, o sea, quien está autorizado a hablar. Está centrada en un sujeto 
que habla (locutor) y establece un espacio de cambios, en el cual se pone en relación con otro (interlocutor). Charaudeau (2012) propone que tal relación se define por algunas características:

a) Características físicas:

- Los sujetos: ¿Están presentes físicamente? ¿El sujeto es único o múltiple? ¿Están cerca o lejos del otro?

- El canal de transmisión: ¿Es un canal oral o gráfico? ¿Es directo o indirecto? ¿Qué otro código semiológico es usado (imagen, grafismos, gestos etc.)?

b) Características identitarias de los sujetos:

- Sociales (edad, género, clase), socio-profesionales, psicológicas (nervioso, frío, amable, espontáneo), relacionales (los sujetos están en contacto por primera vez o no, ya se conocen o no).

c) Características contractuales:

- Cambio / no cambio: el contacto admite un cambio dialogal o no (monologal).

- Rituales de abordaje: constituyen las restricciones, obligaciones o condiciones de establecimiento del contacto.

- Los papeles comunicativos: son los papeles que los sujetos asumen en consecuencia del contrato que establecen.

En otro texto, Charaudeau (2004) esclarece que cada situación es particular porque inscribe, en el nivel de sus componentes, los datos generales del dominio de comunicación (político, mediático, académico, jurídico, etc.) y, también, trae especificaciones propias. Por ejemplo, el dominio político de comunicación tiene una intención (incitación), una identidad de los sujetos (el ciudadano, el político, el adversario) y un cierto propósito (el bien social).

En seguida son presentados los tipos de intención (del francés visées discursives, como objetivo, contemplación o enfoque), según el análisis propuesto por Charaudeau (2004), de los cuales se seleccionan aquellas que interesan a esta investigación:

- Visée de prescripción:

YO quiero mandar una acción porque tengo autoridad para eso.

TÚ estás en posición de deber hacer. 
- Visée de incitación:

YO quiero mandar hacer, pero, como no estoy en posición de autoridad, debo hacer creer que TÚ serás beneficiado.

TÚ estás en posición de deber creer que, si actúas, es para tu propio bien.

- Visée de demostración:

YO quiero establecer la verdad y muestro pruebas, porque tengo la autoridad de saber.

TÚ estás en posición de tener que recibir y tener que avaluar una verdad para tener la capacidad de hacer lo indicado.

Las visées están relacionadas con la intención y la finalidad de la situación comunicativa, que puede seleccionar una o más visées, entre las que una es la dominante.

\subsection{El dissensus y la polémica en el juego argumentativo}

La polarización ideológica de una sociedad se genera a través del discurso, que se difunde en las opiniones originadas en el sentido común y también en los medios, que consiguen ponerlo en funcionamiento debido su gran alcance de difusión. Del combate discursivo entre grupos sociales nace la polémica, con una función importante en el ágora democrática. La polémica es una construcción discursiva que moldea la comunicación en el espacio público, organizándola alrededor de cuestiones controvertidas de interés general.

De acuerdo con Amossy (2014), la polémica se organiza en la esfera democrática: su naturaleza es parte del debate público y de la deliberación política. En esa esfera se encuentra el dissensus como categoría estructurante en la gestión de los conflictos de opinión. Amossy nos dice que la palabra clave para entender la polémica es este concepto de dissensus, cuyo significado descansa en la definición de una división violenta o profunda de sentimientos, intereses, convicciones y opiniones que reside en el sistema de pensamientos, creencias y juicios de aquellos que están en desacuerdo.

Si hay conflicto de opinión es porque existe un ambiente democrático donde encuentran apoyo la diversidad y la libertad de pensamiento y expresión. En ese sentido, la importancia de la polémica se debe al hecho de posibilitar la confrontación pública generadora de comunidades de protesta y de acción política que articulan la transformación social. Aceptar la polémica en un debate es un desafío a la legitimación de desacuerdos sociales. 
La autora (2014) hace un recorrido por los estudios retóricos, iniciados con Aristóteles, quien sitúa la retórica como el arte de negociar diferencias para llegar a un acuerdo:

Habida cuenta de que el uso de discursos persuasivos tiene como finalidad llegar a una decisión (ya que para lo que sabemos y para lo que ya hemos decidido no hay necesidad de discurso alguno), tanto da si se usa el discurso para inducir o disuadir a una sola persona (Aristóteles, 2014: 209).

Para llegar a una decisión común entre las partes, es necesario el reconocimiento de las opiniones irrenunciables que instauran el dissensus. En la perspectiva de Amossy (2014), el dissensus es el gran motor de la democracia porque pone en evidencia la pluralidad de voces disonantes.

De un lado, hay una visión negativa del dissensus ya que lo interpreta como imposibilidad de llegar a un acuerdo y con eso, a una solución para un conflicto. Por otro, hay un movimiento de revaloración del dissensus (en el cual se sitúa Amossy), que lo entiende como una dinámica creadora). La autora (2014) se opone a una concepción dominante en la que prevalece el acuerdo en la deliberación democrática. Tal posición evidencia dos ejes: la vitalidad del antagonismo ideológico como generador del conflicto que provoca cambios sociales y el establecimiento de la diferencia como categoría positiva que añade ideas que pueden ser apropiadas por cualquier grupo.

La cultura del consenso puede ser una visión amenazadora para la democracia porque crea la ilusión de una homogenización del pluralismo identitario, de una unión entre los miembros que son parte de una colectividad. La anulación del otro no es parte de la democracia porque en ella es legítima la coexistencia de adversarios. Amossy (2014) explica que un adversario es un enemigo, pero un enemigo legítimo con el cual luchamos con base en principios comunes de la democracia liberal: la libertad y la igualdad.

Cuando se instituye el otro como enemigo -y no como adversario- se abre camino a la violencia verbal (y a veces física), que se funde en el lema «el enemigo debe ser destruido o eliminado». De esa manera, se elimina la interacción política basada en el conflicto. Como dice Amossy, el conflicto es inevitable en las democracias pluralistas; el nervio de la democracia no es el consenso, sino la gestión del dissensus. Luego, la polémica, como confrontación verbal de las opiniones contradictorias que no llevan a un acuerdo, debe ser considerada funcionalmente como retórica del dissensus.

La principal característica de la polémica es actuar como una cuestión actual de interés público. Esta aparece en un debate de la actualidad para marcar la oposición entre discursos antagonistas. La confrontación verbal sería la 
condición misma de su existencia, siendo una modalidad argumentativa que se sostiene en una doble estrategia: demostrar una tesis y rebatir-descalificar una tesis adversaria. «La polémica, que trata de cuestiones de interés público, es una gestión del conflicto caracterizada por una tendencia a la dicotomización que hace problemática la búsqueda de un acuerdo» (Amossy, 2014: 58). ${ }^{2}$

La dicotomización organizada en el discurso es una especie de síntoma de una división ya instalada en el seno de la sociedad que marca un nosotros y un ellos. La retórica de la polarización concentra un grupo alrededor de una identidad para establecer una frontera entre campos sociales enemigos. Tales campos se hunden en tesis antagónicas e irreconciliables sostenidas por identidades premoldeadas en dicotomías: derecha versus izquierda, antidiscriminación versus tradición, laico versus religioso, etcétera.

La polarización revela visiones de mundo, creencias, juicios diferentes que las identidades agrupan. Pero no solo eso. Esta consolida la identidad de un grupo en detrimento de otro, considerado como enemigo común. La exacerbación de las oposiciones se puede dar por la estrategia retórica de la difamación, por la cual el adversario deja de ser creído porque representa el mal o el error. Por esa estrategia, el enemigo se enflaquece al ser deslegitimado, lo que significa que puede perder su credibilidad en la esfera pública.

En el dominio político, Charaudeau (2013) esclarece que la moralidad es una de las condiciones en que se fundamenta la legitimidad. El sujeto debe ser reconocido como virtuoso, es decir, no puede desviarse de la ley o de las reglas institucionales a riesgo de perder su representatividad. El principio básico de la legitimidad es el reconocimiento: alguien es legitimado por el cuerpo social a actuar o hablar en su nombre por el respaldo de una creencia colectiva.

El ataque al otro se organiza en la deconstrucción de su imagen, que pasa a ser indigna de confianza. Discursivamente, tal ataque puede aparecer en una reformulación y/o deformación orientada del habla del otro y en ironías, por ejemplo. El descrédito que se lanza sobre el enemigo anula su fuerza argumentativa y, políticamente, su influencia.

Un tipo de argumento usado para deconstruir la imagen del enemigo común es la falacia ad hominem, orientada a descalificar su persona, no su habla. Ese recurso para hacer callar al otro tiene el objetivo de excluirlo del diálogo al relacionarlo con la encarnación del mal absoluto. El otro es demonizado y pasa a ser odiado. El intento de denigrar al otro se hace por la exageración, por el ataque hiperbólico sobre su subjetividad, lo que contribuye a moldear su imagen.

2. Traducción del original: «La polémique, qui traite de questions d'intérêt publique, est une gestión verbale du conflictuel caractérisée par une tendance à la dichotomisation qui rend problématique la quête d'un accord». 
De alguna manera, el sujeto demonizado necesita lidiar con esa imagen que es construida para él porque esta interfiere en su ethos, la imagen que uno mismo se construyó. Una vez que su credibilidad es atacada, el sujeto tiene que reconfigurar su ethos para no dejar de ser digno de fe. El ethos se constituye de un cruce de miradas y está sometido a la situación comunicativa. De acuerdo con Charaudeau (2013), el ethos es inestable y está siempre en construcción. Los políticos, por ejemplo, tienen que constantemente preservar su imagen para reconstruir su ethos.

\section{DISEÑO DE LA INVESTIGACIÓN: LA ORGANIZACIÓN DISCURSIVA DEL DISSENSUS}

Después de considerar conceptualmente el dissensus y la polémica, se analizarán los carteles de las protestas de 15 de marzo en Brasil contra la presidenta del país, Dilma Rousseff. Para el análisis, se seleccionaron 20 carteles que desfilaron por las calles de muchas ciudades brasileñas donde su población se organizó por la red social Facebook para protestar contra el gobierno del Partido de los Trabajadores (PT) y la presidenta recién electa, Dilma Rousseff. Esos carteles fueron divulgados por varios vehículos de comunicación accesibles por Internet.

Debemos tener en cuenta las características de la situación de comunicación: los sujetos involucrados en las protestas son los ciudadanos brasileños insatisfechos con la corrupción en la política nacional, que fue asociada por los partidos de oposición al Partido de los Trabajadores y cuya representación llegó a los medios de comunicación. Algunos actores políticos son los destinatarios de los carteles de las protestas, ya que sus nombres aparecen en ellos y sus textos les son dirigidos. Pero el principal destinatario de estos textos es la presidenta Rousseff y claro, su partido.

Tomando como referencia la propuesta de Charaudeau comentada en el marco conceptual, se evaluarán en el proceso de análisis las siguientes características:

a) Físicas:

- Los sujetos no están presentes físicamente, solo los sujetos ciudadanos están en las calles, luego están lejos del otro (los políticos); el sujeto es múltiple o colectivo.

- Los canales de transmisión son: oral (los manifestantes verbalizan sus insatisfacciones), gráfico (carteles), en imágenes (dibujos, collages) y con gestos. 
b) Identitarias de los sujetos:

- Sociales: la mayoría de los ciudadanos presentes en la protesta de la más grande ciudad de Brasil, São Paulo, son hombres con una edad media de 40 años, tienen estudios superiores, son económicamente activos y se autodeclaran blancos. ${ }^{3}$

- Psicológicas: pese a dificultad de abordarlo, fue posible observar que había personas protestando racionalmente, luchando por más derechos sociales y menos corrupción de manera razonable, y otras más pasionales que proferían insultos.

- Relacionales: al tratarse de una protesta multitudinaria, los sujetos probablemente estaban en contacto por primera vez.

c) Contractuales:

- El contracto es monologal, porque los políticos a los cuales los insultos y reclamos fueron dirigidos no estaban presentes en la protesta.

- Rituales de abordaje: la principal restricción de una protesta democrática es que las personas tengan el derecho de manifestar sus opiniones y respetando a aquellas con quien divergen. Luego hay una obligación de no ejercer la violencia, sea verbal, sea física.

- Los papeles comunicativos: el papel del ciudadano es expresar sus insatisfacciones y quejas, exigir que se cumplan sus derechos por parte de aquellos que son sus representantes por la vía electoral. El papel del criticado, en el caso de los políticos, es permitir el ejercicio pacífico de ese derecho, sin usar la fuerza policial para contenerlo.

Metodológicamente, los carteles fueron organizados en cuatro grupos temáticos:

- Grupo 1: agresiones

Carteles en los cuales se encuentran insultos verbales y visuales, amenazas/deseo de muerte a Lula da Silva y Dilma Rousseff, estimulación de la violencia o acusaciones.

3. Datos investigados por los institutos estadísticos de Brasil FPAbramo y DataFolha. 
- Grupo 2: dicotomización

Carteles en los cuales hay polarización ideológica por la construcción de nosotros versus ellos; marxismo/comunismo versus Brasil liberal; élite versus Partido de los Trabajadores (PT).

- Grupo 3: impeachement

Carteles en los cuales hay la asociación de la corrupción a un único partido (PT); uso semántico de los colores rojo (PT) versus verde y amarillo (nacionalismo/ militarismo).

- Grupo 4: intervención militar

Carteles en los cuales se pide la intervención militar como salida para salvar el país con el uso de verbos que expresan deseo y demanda de intervención, golpe militar o rescate externo.

\section{RESULTADOS}

\subsection{Agresión: el límite del insulto}

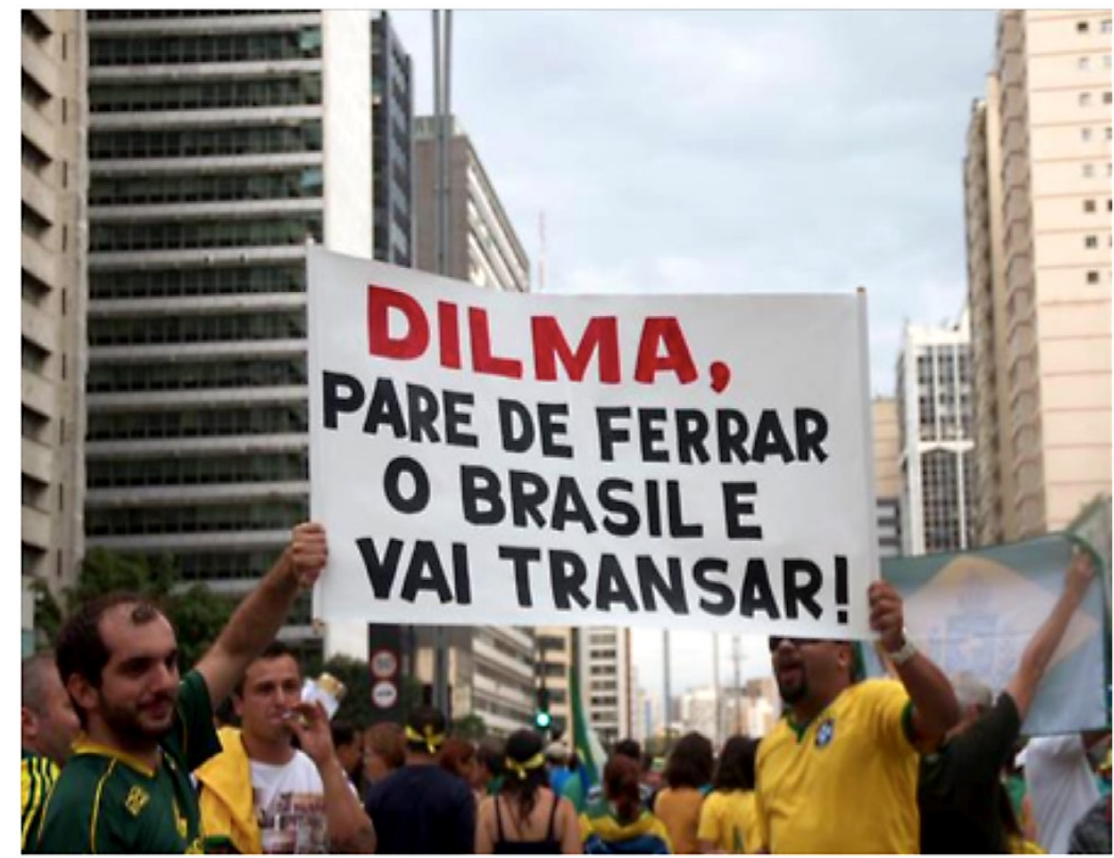

Figura $1^{4}$

4. Traducción: «Dilma, no jodas más a Brasil y vete a follar». 


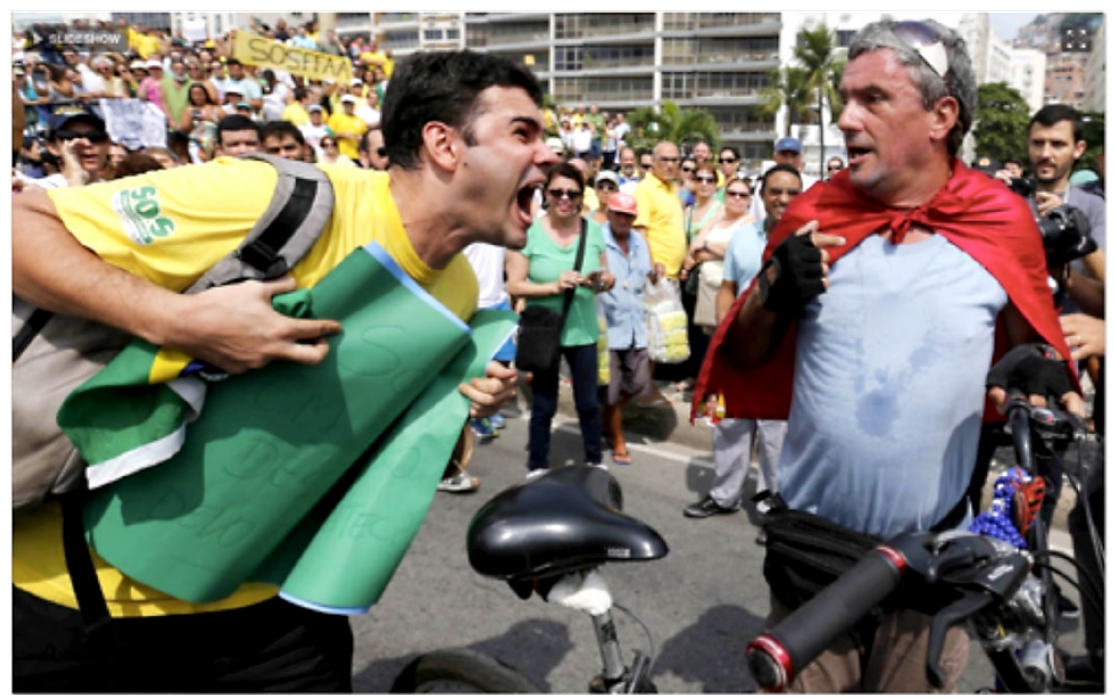

Figura 2

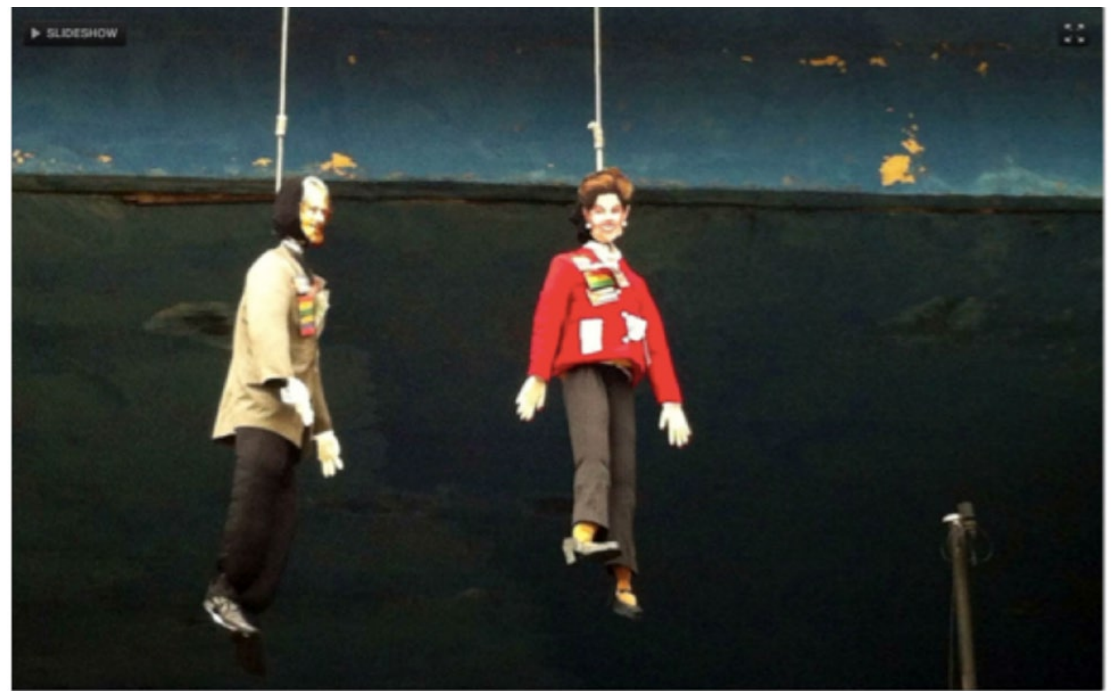

Figura $3^{5}$

5. Marionetas que representan el ahorcamiento de Dilma Rousseff e Ignacio Lula da Silva. 


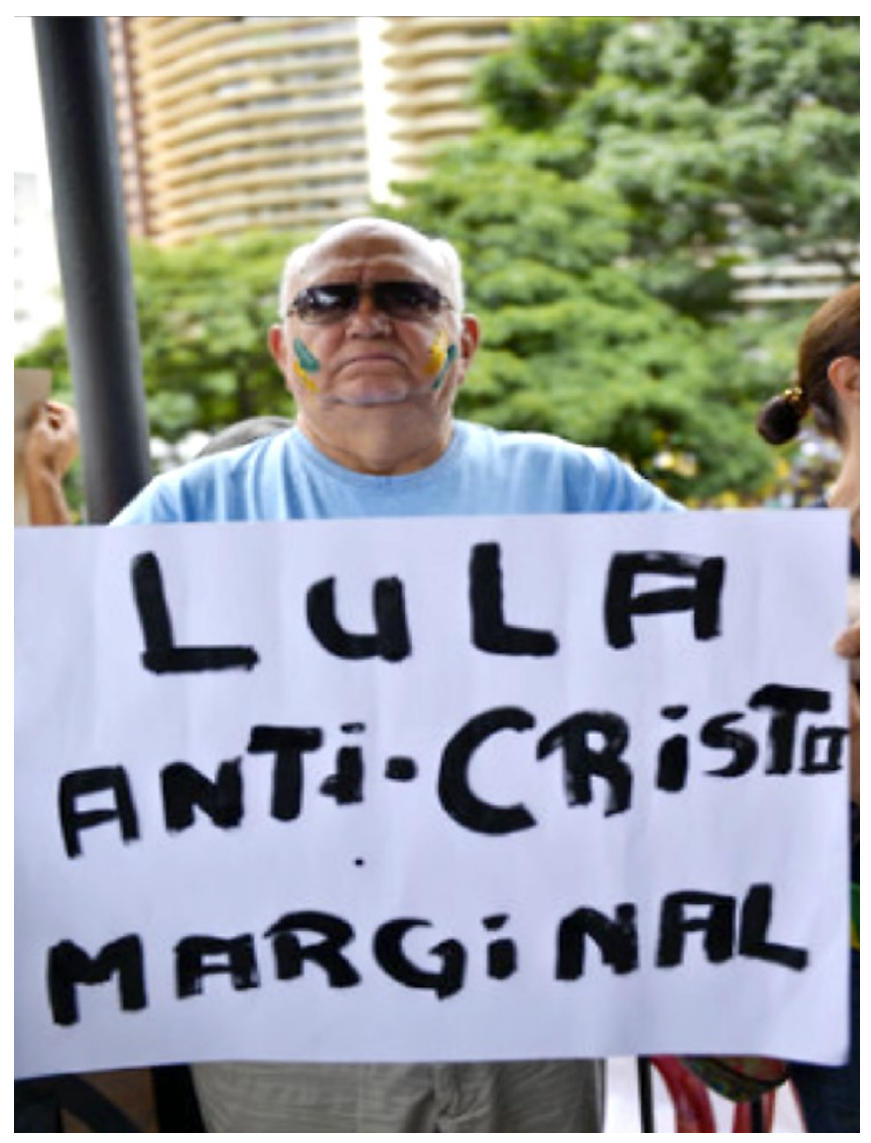

Figura 4

Dos hombres están agarrados a un cartel que insulta a la presidenta Dilma Rousseff (figura 1). La estrategia del insulto es utilizada intencionalmente por las elecciones léxicas vulgares ferrar y transar dirigidas a un presidente al cuestionar su legitimidad, sobre todo porque ese cargo lo ejerce una mujer. ¿ $\mathrm{Si}$ un hombre estuviera en la presidencia leeríamos un cartel sugiriéndole tener relaciones sexuales para no hacer más daño al país? En 1992, cuando millones de personas protestaron exigiendo el impeachment del entonces presidente, Fernando Collor de Mello, no había carteles con ese tipo de contenido ofensivo. 


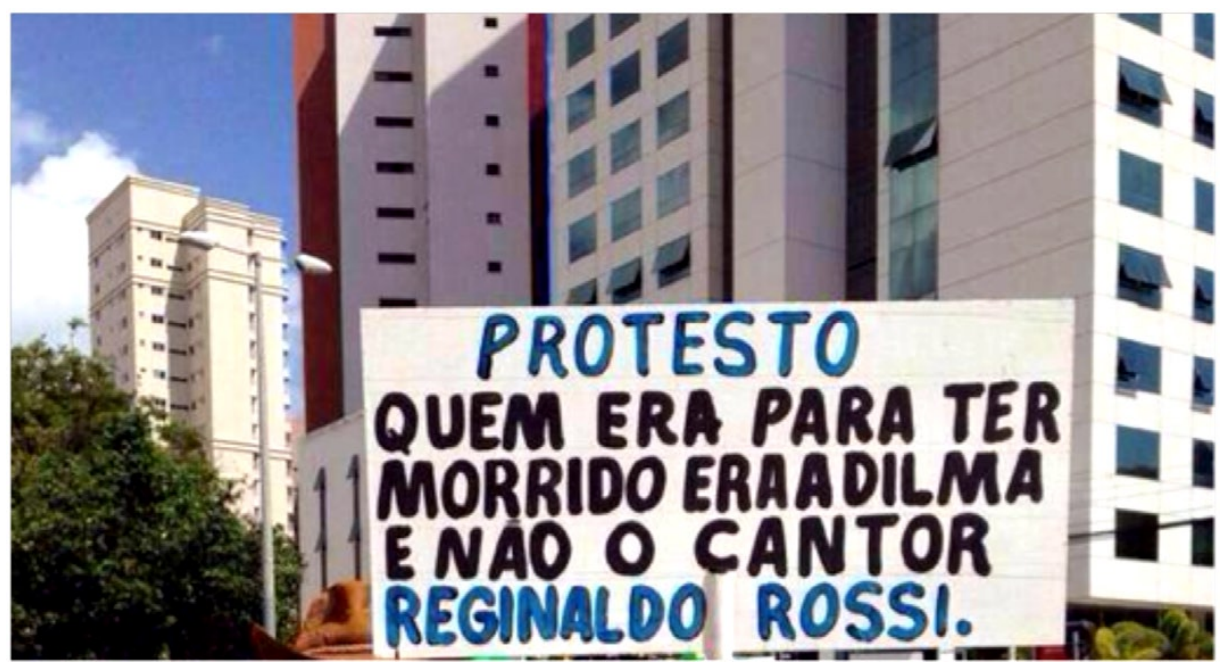

Figura $5^{6}$

El insulto es un tipo de violencia verbal que tiene una tonalidad agresiva. La violencia sexista contra la presidenta presupone que ella ejerce un mal gobierno porque tiene «problemas sexuales». Aun según Amossy, el polemista, en su acto de lenguaje, usa el insulto para atribuir al otro unas características que le descalifican, creyéndose en el derecho de situarlo en una posición baja.

Dos carteles (figura 3 y figura 5) manifiestan el deseo que la presidenta esté muerta. Ese es el grado máximo de anulación del otro a través de un silenciamiento total, que es la muerte del adversario.

Los carteles de ese grupo instituyen a Rousseff (y también a Lula da Silva) como un enemigo a ser combatido -y no un adversario ideológico-, lo que abre camino a la violencia verbal e implícitamente física para que el enemigo sea eliminado.

6. «Protesta. Quien debía estar muerta es Dilma, no el cantante Reginaldo Rossi» (cantante muy popular en Brasil fallecido en 2013). 


\subsection{La dicotomización como imposibilidad de diálogo}

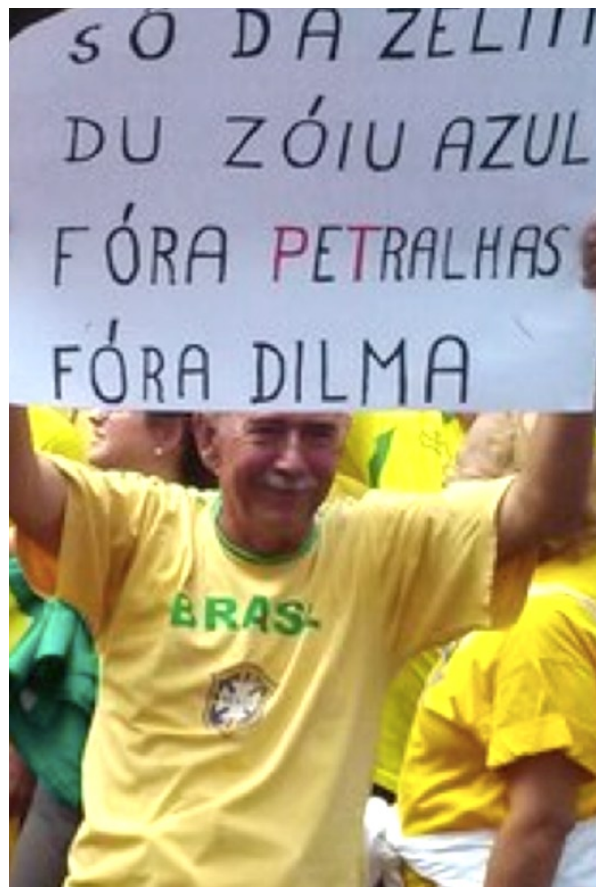

Figura 6

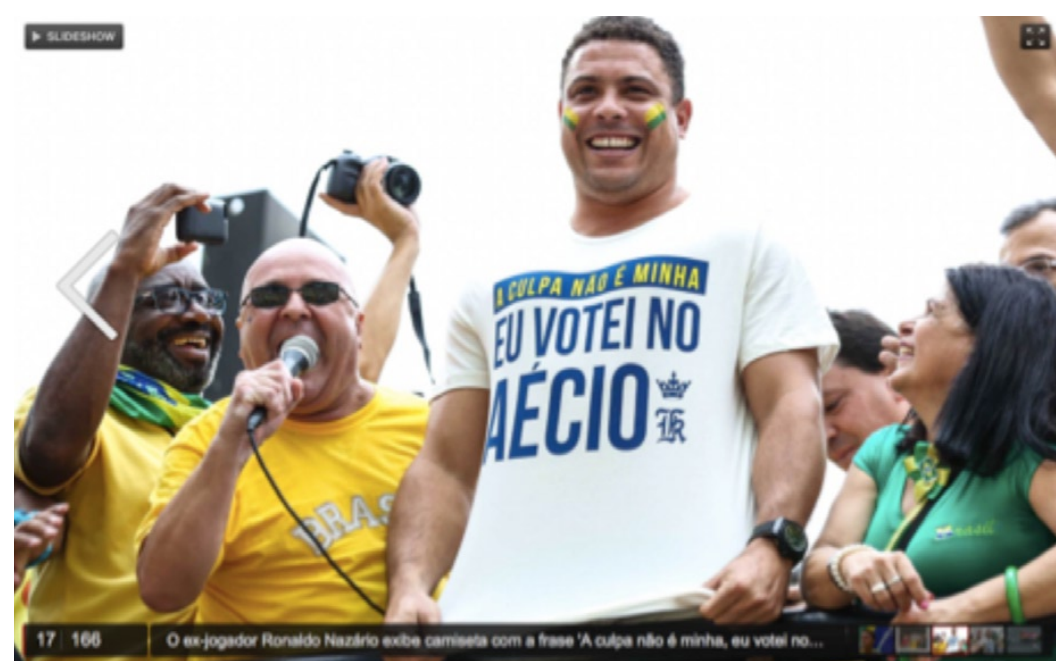

Figura 7 


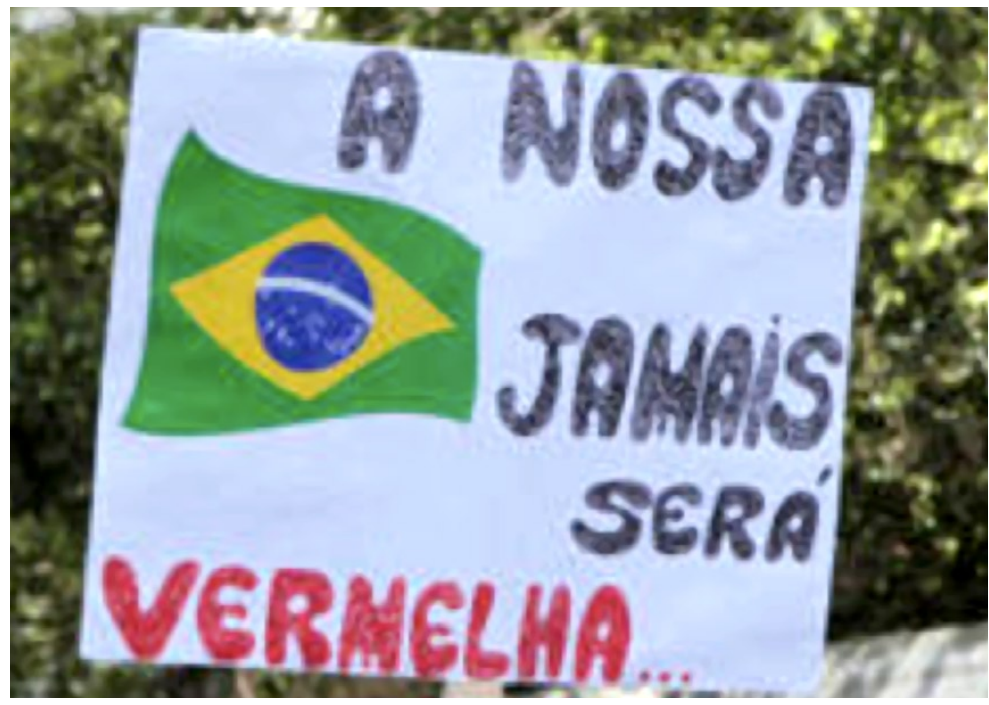

Figura 8

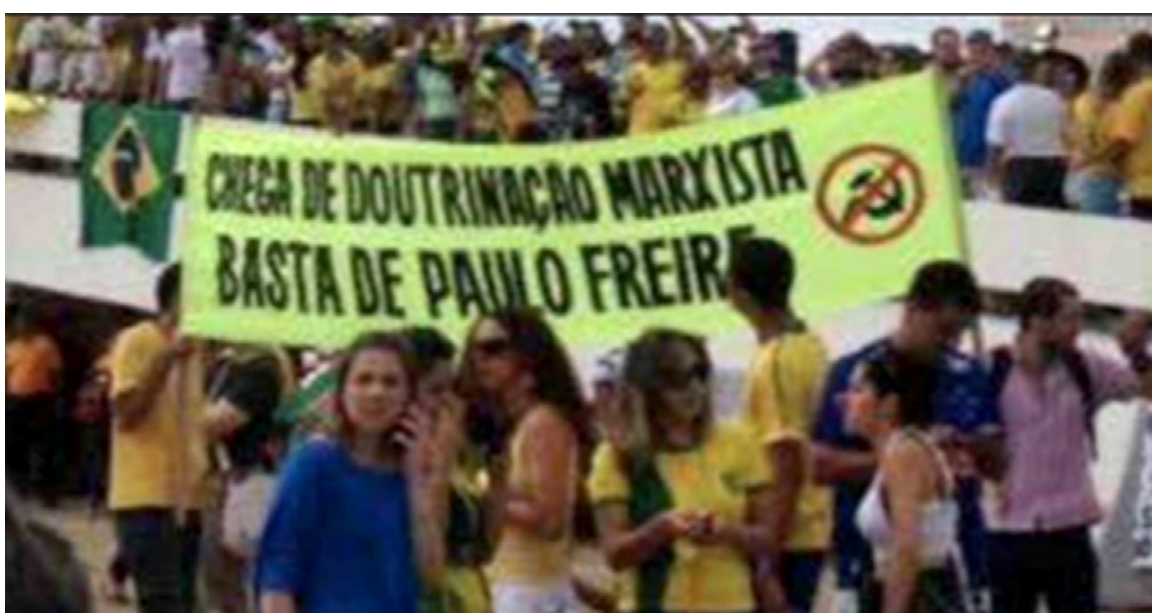

Figura $9^{7}$

7. En referencia al educador brasileño Paulo Freire, el cartel dice que basta de doctrina marxista en las escuelas de Brasil. 


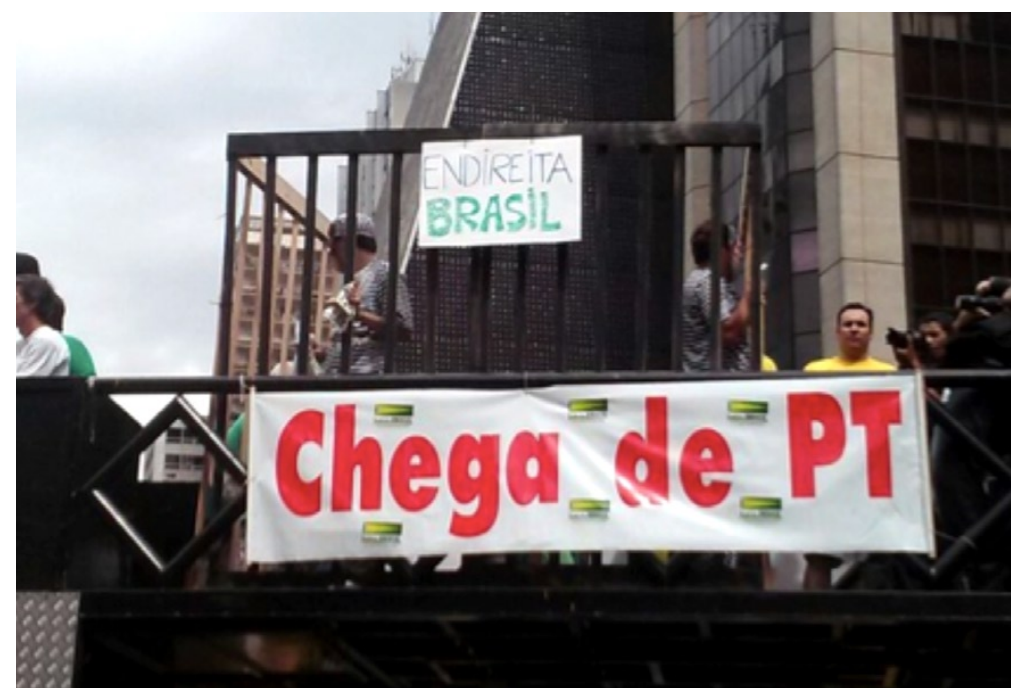

Figura $10^{8}$

El dueño del cartel de la figura 6 es un hombre blanco de ojos azules, y lo manifiesta orgulloso, haciendo uso de una variedad lingüística más popular, que en una traducción a la norma culta sería: «Soy de la élite, tengo los ojos azules, fuera PeTralhas, fuera Dilma.». Con pocas palabras, el actante hace tres tipos de polarización: clase (ricos frente a pobres), étnica (negros/mestizos frente a blancos) e ideológica (derecha frente a izquierda). El PT es descalificado por su supuesta asociación a los pobres, en su mayoría población negra en Brasil, poniendo en discusión el problema de la lucha de clases que se evidenció en los últimos doce años con la ascensión de los más pobres a la clase media consumidora. Se presupone que, con la salida del PT del gobierno, la clase media simbólica no sufriría la amenaza de la pérdida de su status quo, ya que los carteles criticaron la corrupción pero no reconocieron los avances de los derechos sociales en Brasil.

8. El sentido en portugués es doble, porque la palabra endireita se refiere a tomar el camino correcto («el camino a la derecha»), y también es una acepción político-ideológica para la derecha. 
No olvidemos que la polémica necesita de polarización. La estrategia de dicotomización exacerba cada opinión poniéndolas en polos excluyentes por la imposibilidad de llegar a una solución. Nosotros contra ellos es el enfrentamiento del bueno contra el malo, de la derecha contra la izquierda.

En los carteles de ese grupo, la solicitud de los manifestantes no es por leyes que garanticen punición a los corruptos o la manutención de los derechos sociales. Las elecciones léxicas fuera, jamás, basta dan muestra de que la única salida propuesta es la expulsión de la presidenta elegida en una estructura democrática de organización social.

\subsection{Impeachment: ¿una salida fuera de la ley?}

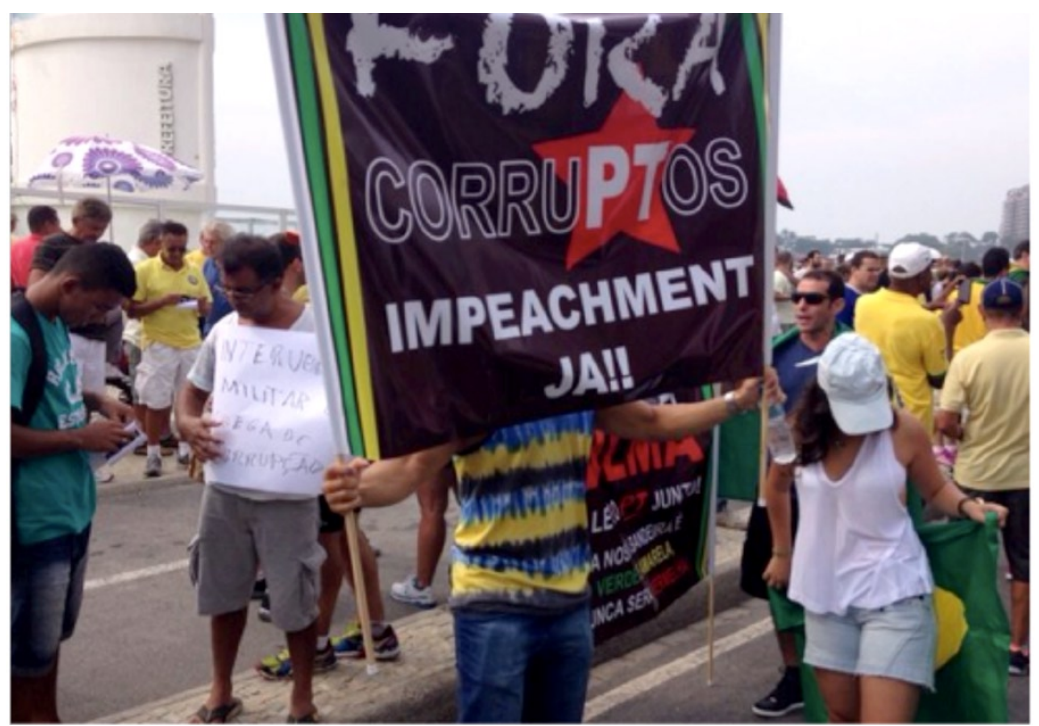

Figura 11 


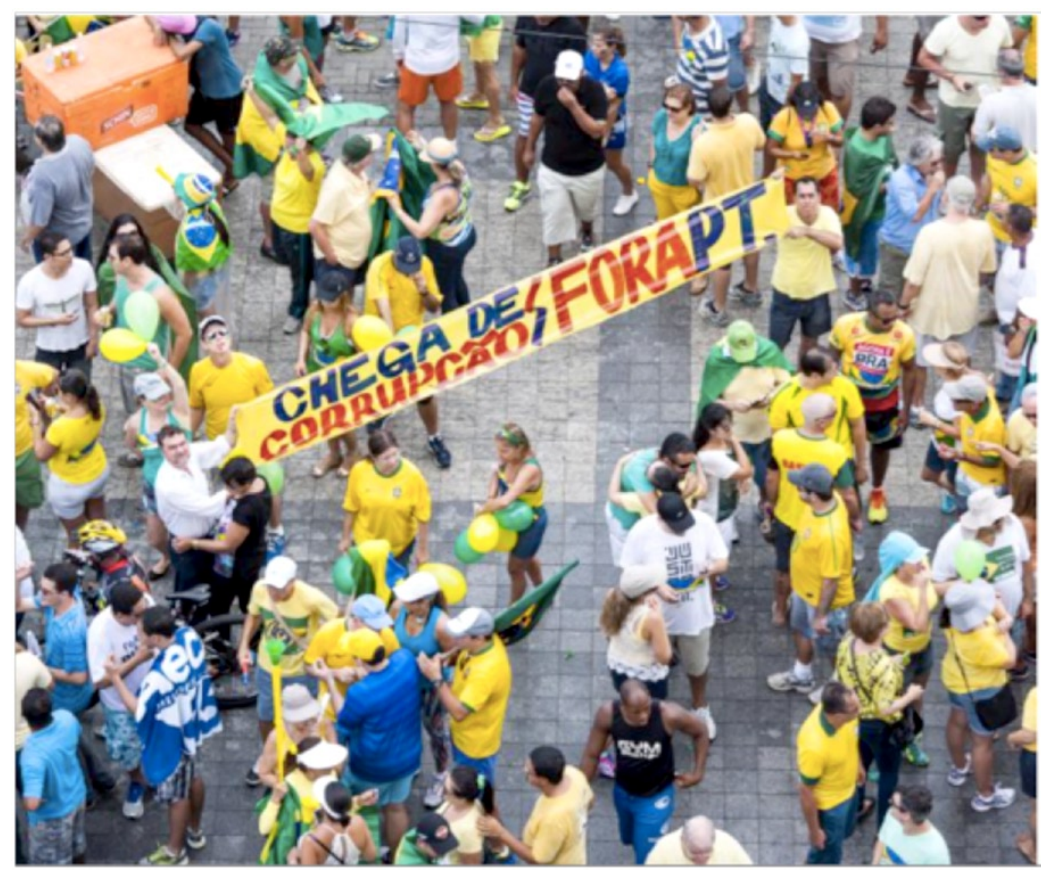

Figura 12

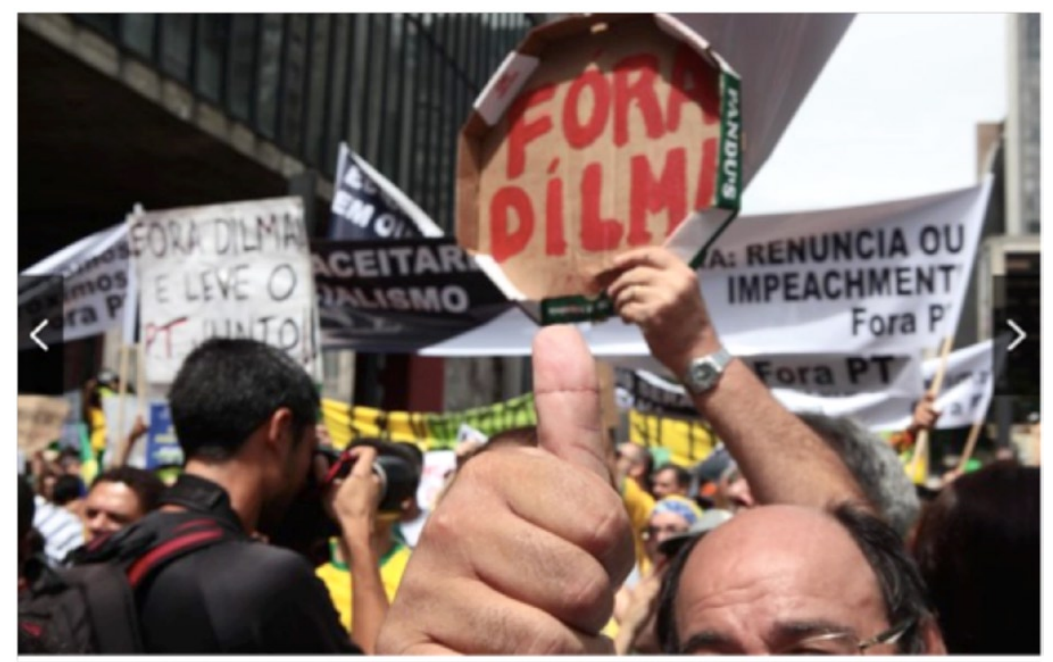

Figura 13 


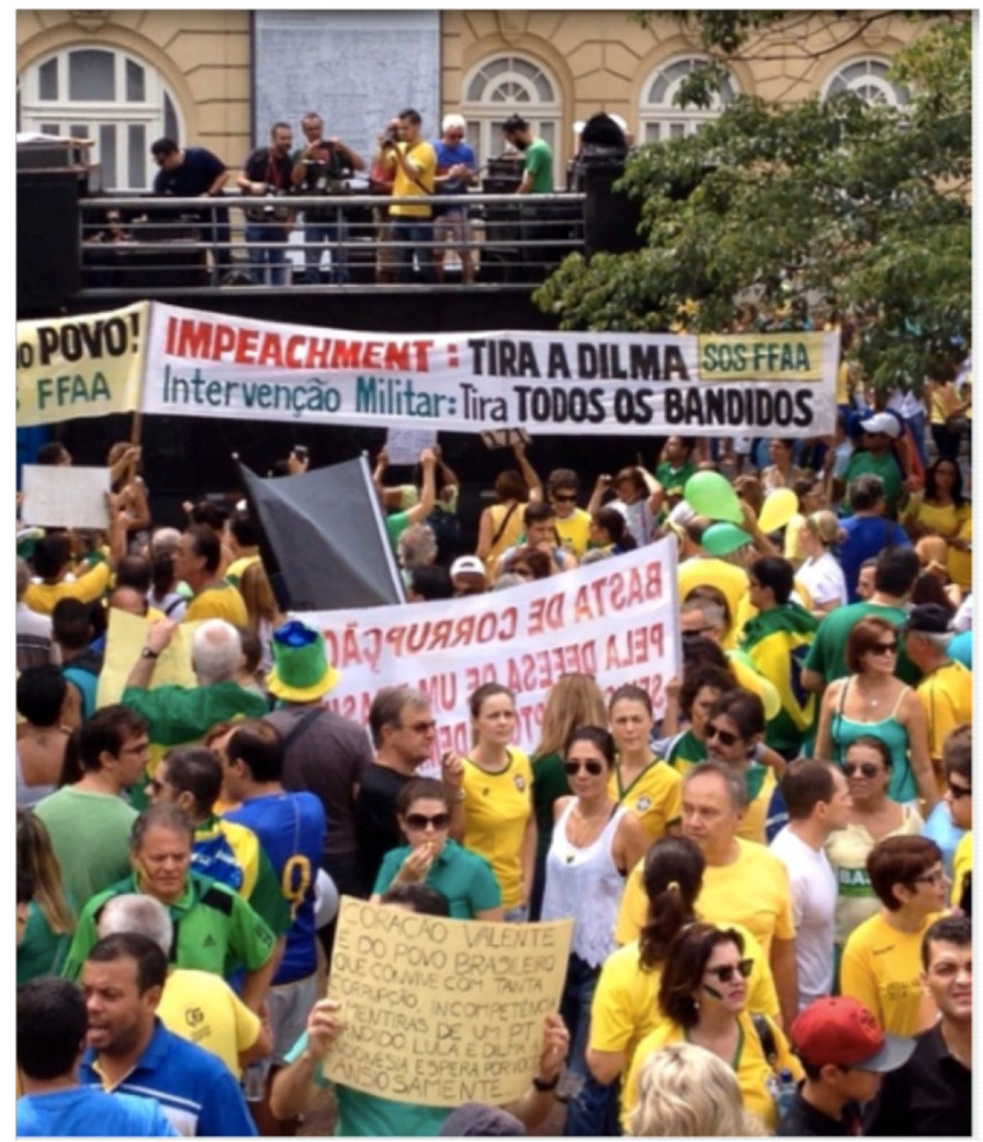

Figura 149

En 1992 Brasil pasó por el primer proceso de impeachment de un presidente en América Latina. Técnicamente, el impeachment es una herramienta prevista en la constitución brasileña válida para casos en que autoridades políticas practican un crimen de responsabilidad administrativa. Se trata de una situación muy grave en la cual la autoridad comete una infracción que provoca la pérdida de su función.

9. El cartel pide a las Fuerzas Armadas de Brasil que ayuden al pueblo sacando a Dilma (y a todos los marginales, en referencia a los políticos) de la presidencia. 


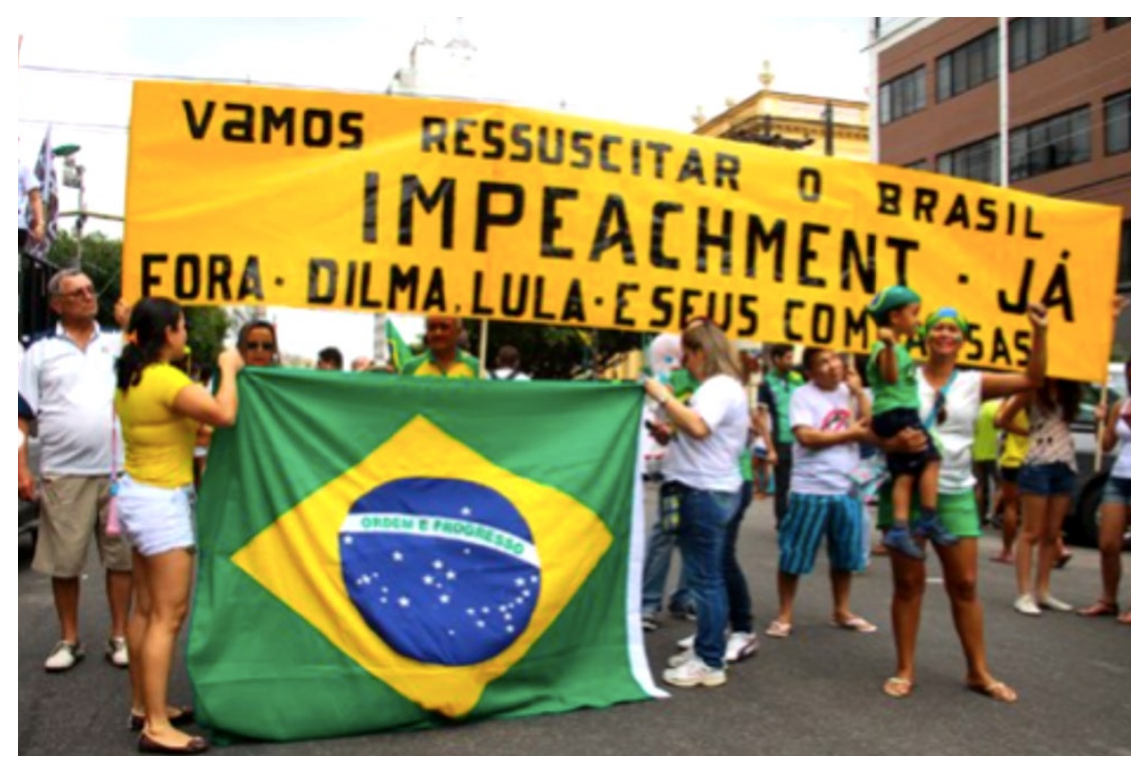

Figura 15

El cartel (figura 3), creado con los colores negro y rojo, es duro y genera una atmósfera pesada, como si Brasil estuviera muriendo por causa de tanta corrupción. Las iniciales del nombre del Partido de los Trabajadores están contenidas en la palabra corruptos, destacada en rojo, color del partido. La dicotomización se presenta nuevamente en el cartel por la asociación exclusiva del PT a los casos de corrupción del país, excluyendo su base política de apoyo e otros casos millonarios de corrupción del partido oponente, el Partido Social Demócrata, que gobierna el estado más rico del país (São Paulo), recientemente involucrado en un caso de desvío de dinero en la construcción del metro de la ciudad de São Paulo.

Los carteles de ese grupo hacen una asociación directa entre corrupción y PT, y piden que la presidenta salga del gobierno en medio del proceso de investigación del caso Petrobrás. 


\subsection{Intervención militar: el fantasma del radicalismo amenaza} la democracia

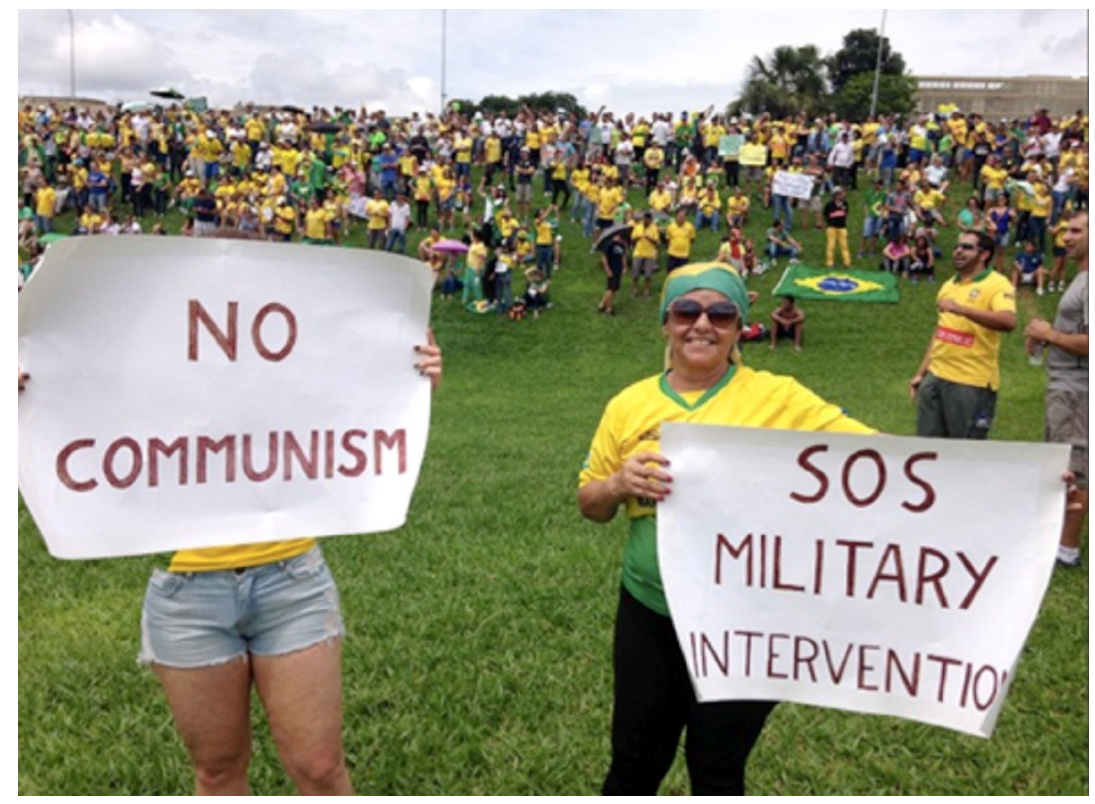

Figura 16

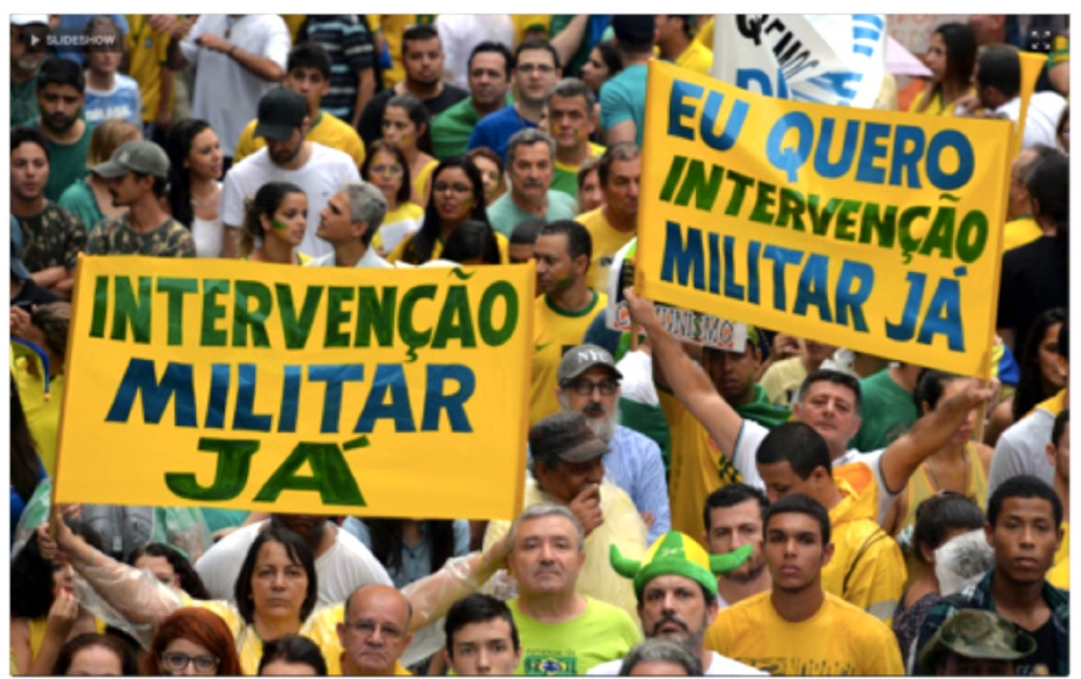

Figura 17 


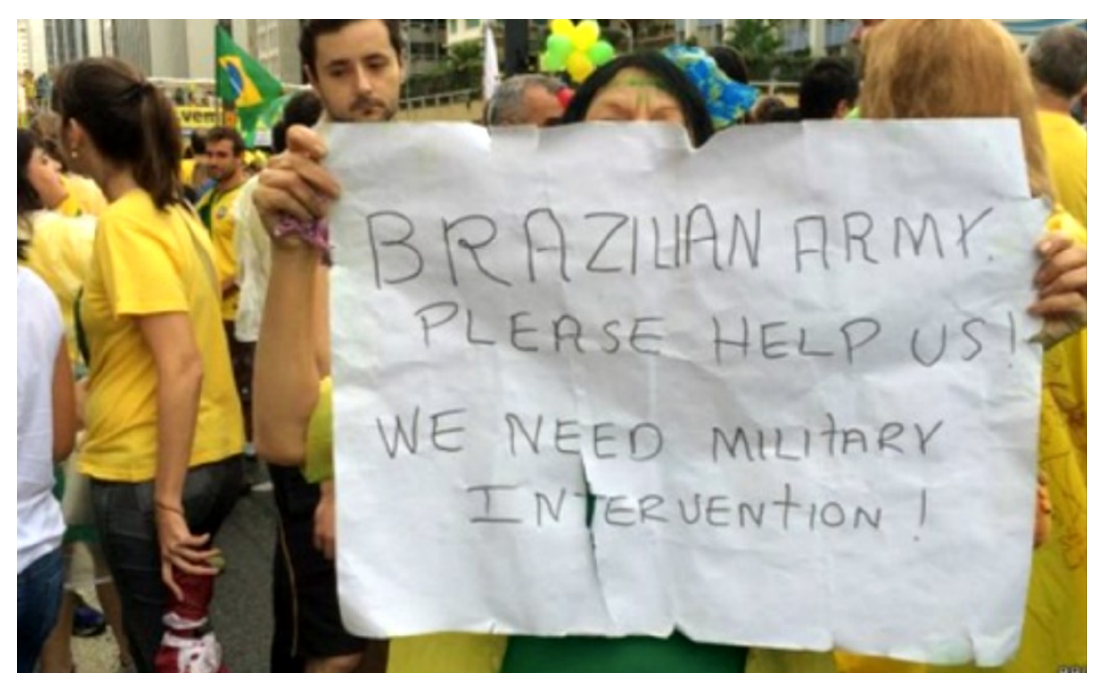

Figura 18

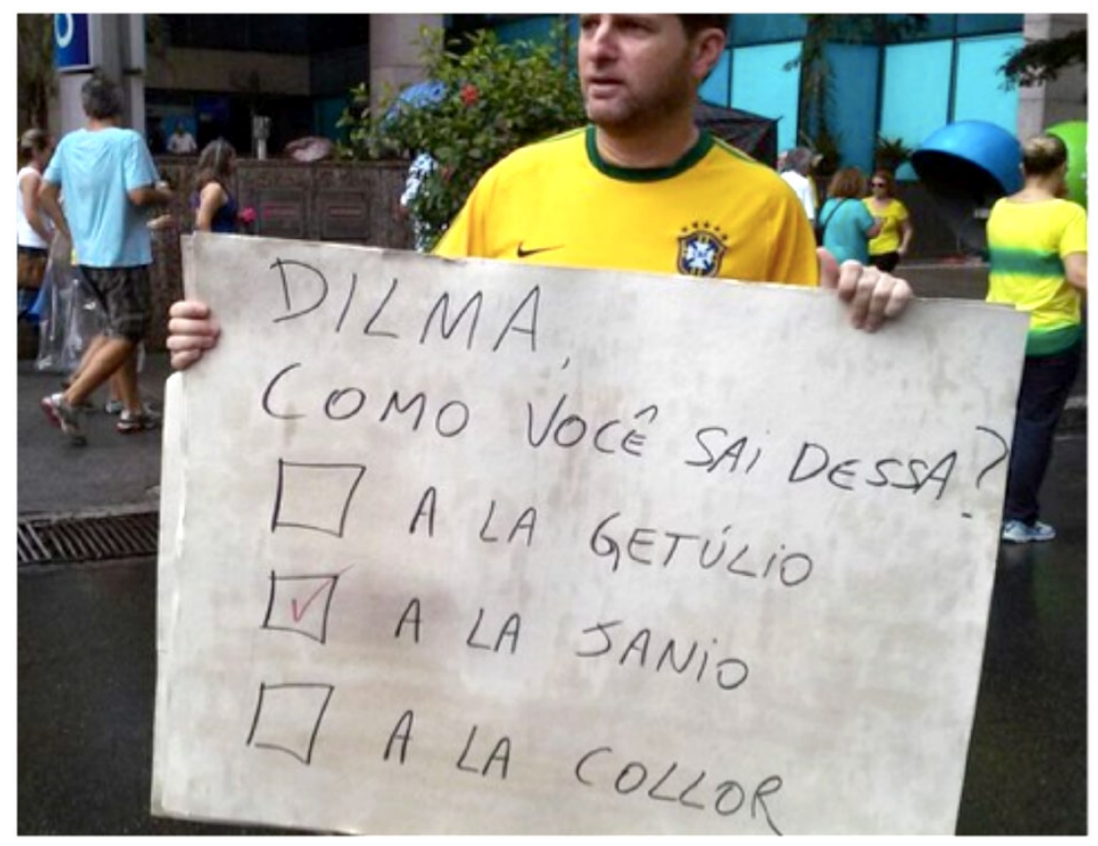

Figura 19 


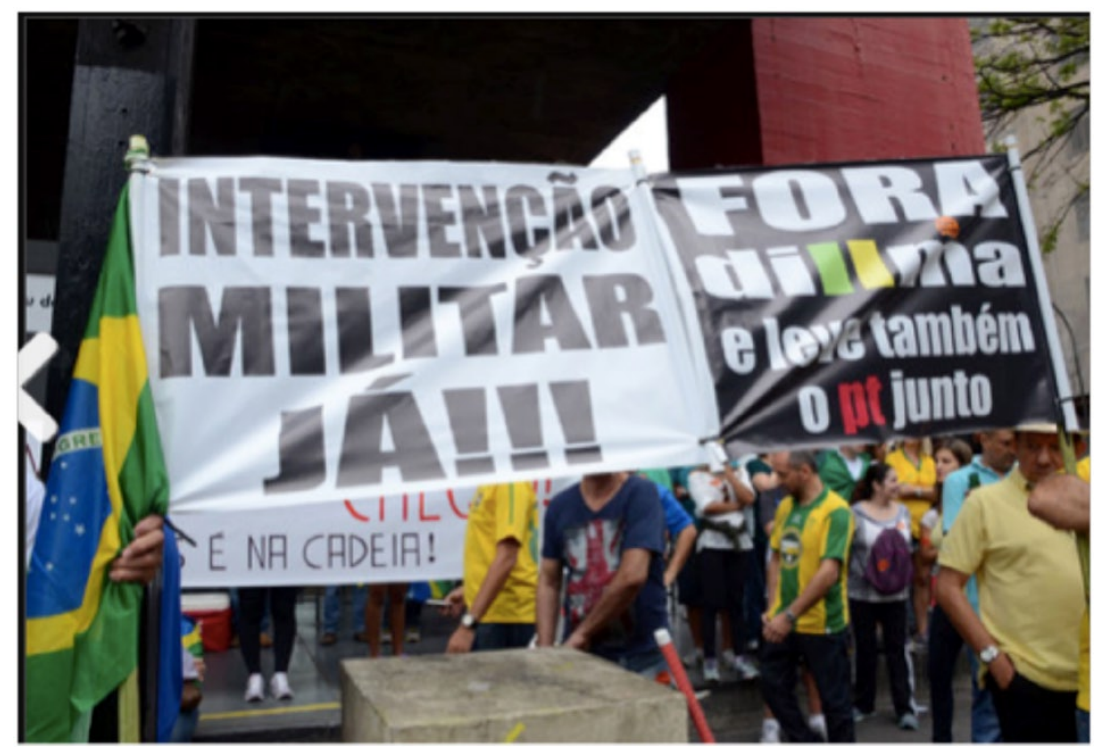

Figura 20

El tapiz verde y amarillo de la multitud (figura 16), con colores que representan a Brasil, remite a un imaginario nacionalista de la dictadura de 1964, que se corrobora con el lema del cartel escrito en inglés. Uno de los valores de la derecha es la patria, símbolo de identificación del cuerpo social con la nación. Diferentemente del discurso de derecha en Europa, que selecciona un enemigo exterior como amenaza nacional, en ese cartel la salvación viene del ejército brasileño con la ayuda de una intervención extranjera, quizás de Estados Unidos, como ocurrió en 1964. En los carteles, la estrategia de polarización está presente: nosotros, juntamente con el ejército, somos una fuerza contra ellos (el gobierno).

El discurso de una cierta derecha en Brasil hace creer a la gente, sobre todo a aquellos que no vivieron los «años de plomo», que el periodo en que Brasil fue gobernado por una dictadura vivía una buena situación económica. Ese discurso se hunde en la ausencia de una resolución histórica de base legal que responsabilice a aquellos que cometieron crímenes políticos en la dictadura. Eso favorece el surgimiento de un discurso que utiliza el odio para constituir un imaginario de radicalismo para la gente, como se hace evidente en el cartel 19, que ofrece algunas opciones para que Dilma Rousseff salga del 
gobierno, sugiriendo la opción «a la Janio» (Janio Quadros), presidente que dejó el gobierno por el golpe de estado de 1964.

\section{5. ¿Cómo comprender la organización discursiva de las protestas?}

Amossy (2014) analiza el discurso radical en la perspectiva de la diabolización del otro, que presenta el adversario como el mal absoluto a combatir. La demonización es una estrategia que exagera la polarización con ataques hiperbólicos que son objeto de una reprobación moral llamada para expulsar dicho mal.

Tanto el caso del impeachment como el de la intervención militar se organizan en un discurso ideológico de una extrema derecha creciente en Brasil, que desea cambiar la situación, aun con el uso de la fuerza, sea por las armas o por un golpe de Estado, como muestran los carteles. La derecha, según muestran los carteles, ha entrado en un duelo por la conquista del poder por la vía de la acusación, del insulto, de la intervención en un momento de decrecimiento económico provocado por una crisis interna afectada por la crisis mundial.

Como ya hemos dicho, la polarización revela distintas visiones del mundo que moldean la identidad de los grupos sociales. La exacerbación de las características del ellos en oposición a nosotros se construye por la asociación de valores negativos a aquellos y de positivos a estos, a través de una falacia de difamación. Esa estrategia fue usada contra Dilma Rousseff en la protesta para enflaquecerla y así, deslegitimarla, lo que políticamente significa un ataque a su credibilidad.

En el dominio político, Charaudeau (2013) esclarece que la moralidad es una de las condiciones en que se fundamenta la legitimidad. El sujeto debe ser reconocido como virtuoso, es decir, no puede desviarse de la ley o de las reglas institucionales, a riesgo de perder su representatividad. El principio básico de la legitimidad es el reconocimiento: alguien es legitimado por el cuerpo social a actuar o hablar en su nombre por el respaldo de una creencia colectiva.

En las protestas, el ataque a Rousseff se organizó con el objetivo de deconstruir su imagen al punto de instituir una crisis de confianza política en Brasil. Tal descrédito que se ha lanzado sobre la presidenta fue orientado a anular políticamente su influencia.

Como ya hemos visto, un tipo de argumento usado para deconstruir la imagen del enemigo común es la falacia ad hominem, orientada a descalificar su persona, no su habla. Ese recurso para hacer callar a Dilma Rousseff y su partido tiene el objetivo de excluirlos del diálogo al relacionarlos con la encar- 
nación del mal absoluto. Ellos son demonizados para que sean odiados. El intento de denigrar a ambos se hace por la exageración, por el ataque hiperbólico sobre su subjetividad, lo que contribuye a moldear la imagen de un político y un partido corruptos.

En los carteles, el color rojo es atribuido al partido del gobierno y a la presidenta, argumentando visualmente en la construcción de la dicotomización ideológica. El color en esos casos funciona como color-información, según el concepto de Guimarães, que se refiere a 'funciones responsables por organizar y jerarquizar informaciones o atribuirles significado, sea por su actuación individual y autónoma o integrada y dependiente de otros elementos del texto visual en que fue aplicada' (Guimarães, 2003: 31). ${ }^{10}$

Según Guimarães (2010), los colores significan. El rojo, por ejemplo, tiene fuerte connotación emocional, asociándose semánticamente a violencia, pasión, amor, guerra. Evidentemente, el color rojo es constitutivo del logotipo del PT, pero ese dato se confunde con las intenciones ofensivas expresadas en los carteles.

Podemos decir, ante el análisis hecho, que la intención (o visée) que orienta el discurso de los carteles es de incitación, una vez que el YO ciudadano quiere mandar hacer que Rousseff salga de la presidencia, pero no tiene posición de autoridad para hacerlo sin que haya pruebas que demuestren razones para su salida. Aunque el enfoque de incitación sea el dominante en los discursos analizados, la visée de demostración también está presente, porque se intenta establecer la verdad de que el PT es corrupto. En los dos tipos de enfoque, $T U ́$, ciudadano, estás en posición de deber creer que se debe excluir a Dilma Rousseff y a su partido del juego político, y para eso es necesario avaluar como verdad la imagen que le es presentada.

\section{CONCLUSIÓN Y DISCUSIÓN}

En general, la presidente y el PT son estigmatizados en los carteles. Según Goffman (2012), el concepto estigma es usado en referencia a un atributo profundamente despreciativo. El estigma es un tipo especial de relación entre atributo y estereotipo que se da por aberraciones corporales (deformidades físicas), culpas de carácter individual (voluntad débil, pasiones tiránicas, falsas

10. Traducción del original: «[...] funções responsáveis por organizar e hierarquizar informações ou lhes atribuir significado, seja sua atuação individual e autônoma ou integrada e dependente de outros elementos do texto visual em que foi aplicada» (Guimarães, 2003, p. 31). 
creencias, deshonestidad), estigmas tribales (raza, nación, religión, política). El estigma es una ideología que intenta explicar a alguien como inferior y el peligro que este representa.

Goffman (2012) nos alerta de que todo problema de la manipulación del estigma sufre influencia de nuestro desconocimiento (o no) personal del sujeto estigmatizado, o sea, de no conocer su identidad personal. Los medios de comunicación ayudan a fabricar una (o varias) identidad(es) para Dilma Rousseff, basadas muchas veces en opiniones terceras o extraídas de sus declaraciones, sin vinculación con su historia personal o con sus declaraciones en un contexto determinado. Aquellos que hacen oposición al Partido de los Trabajadores -políticos y algunos medios-, la caracterizan como incompetente y autoritaria.

Las opiniones que son estampadas en los carteles dan muestra, limitada pero cualitativa, de que hay una división ideológica en la sociedad brasileña también difundida en los medios de comunicación, que polarizan los discursos del gobierno y de la oposición y, en algunos casos, declaran cuál es su posición en relación a uno de los polos.

Charaudeau (2013b) nos enseña que la opinión está intrínsicamente relacionada con la democracia, por ser el espacio común de reencuentro de voces diferentes. Se trata de una visión del mundo de carácter subjetivo en los planos emocional y racional. En los carteles se pone en cuestión la incomunicabilidad de las voces que habitan hoy la vida democrática brasileña, porque los sujetos que marchan con sus carteles no están dispuestos a aceptar una discusión y, así, una solución dialogada. Sus salidas (cuando proponen una) para los problemas del país no pasan por una tentativa de consenso, de acuerdo, de ponderación sobre argumentos que puedan llevar al bien común. Tampoco se puede percibir en las protestas una madurez democrática que reconozca como principio la pluralidad. Retomando a Amossy (2014), el punto neurálgico de la democracia es la gestión del dissensus, y no la anulación del otro por la imposición de una homogenización social. Luego, la polémica en el plano verbal pone en evidencia las contradicciones sociales que no siempre llevan a un acuerdo, sino a negociaciones.

En ese sentido, como afirma Van Dijk (2015a), el sistema de dominación provoca un sistema de rebeldía. Las protestas en Brasil son ideológicas y asumieron la forma de polarización social: nosotros versus ellos. Las estrategias discursivas que se encuentran en las imágenes y en los textos de los carteles atribuyen un valor positivo a nosotros y un valor negativo a ellos, observable por las elecciones sintácticas, léxicas y semánticas.

Una parte de la sociedad brasileña parece no tener en cuenta que las diferencias de opinión son parte de la vida democrática, ya que muchos sugieren el 
fin de la democracia con la intervención militar, con el «fuera Dilma» sin un proceso legal, lo que caracterizaría un golpe de estado.

La modalidad de afirmación de las opiniones en los carteles se da por la anulación del otro, como si el grupo que salió a las calles el 15 de marzo fuera un cuerpo social hablante homogéneo. Ese cuerpo social que habla y tiene legitimidad para hacerlo (justamente porque Brasil es un país democrático) parece no saber que, como nos alerta Charaudeau (2013: p. 165), la democracia no es un régimen político ni un tipo de gobierno: «elle est, elles aussi, un principe transcendental de gouvernance des peuples». ${ }^{11}$ Solo puede haber democracia porque el pueblo entiende y conoce su poder y fuerza, que se convierten en un derecho legal en el cual se basa que todos los seres humanos son iguales. La democracia tiene una función crítica porque a través de su ejercicio el pueblo puede fiscalizar las reglas del juego de la dominación.

La investigación lo muestra con las herramientas de análisis argumentativo que se han priorizado en el marco teórico, limitado a propósito de una buena fundamentación orientada al diseño metodológico. Y si bien es cierto que la argumentación tiene muchas escuelas, no lo es menos que desde la retórica clásica, la deliberación pública ha de estar marcada por las razones y no por el insulto y la amenaza, que son emociones que contaminan los argumentos convertidos en falacias. En el caso brasileño, y a pesar de la ejecución del impeachment, están en juego la paz social y las reglas de juego político de la democracia electoral.

\section{REFERENCIAS BIBLIOGRÁFICAS}

Amossy, R. (2014): Apologie de la polémique, París, Presses Universitaires de France.

Aristóteles (2014): Retórica, Madrid, Alianza Editorial.

Charaudeau, P. (2004): «Visadas discursivas, gêneros situacionais e construção textual» en MaChado, I.; R. DE Mello Gêneros reflexões em análise do discurso, Belo Horizonte, Nad/Fale-UFMG.

- (2012): Linguagem e discurso: modos de organização, São Paulo, Contexto.

- (2013 a): Discurso político, São Paulo, Contexto.

- (2013 b): La conquête du pouvoir: opinion, persuasion, valeurs. Les discurs d'une nouvelle donne politique, París, L'Harmattan.

11. Traducción del original en francés: Esta es un principio transcendental de gobierno de los pueblos. 
—; Maingueneau, D. (2014): Dicionário de análise do discurso, São Paulo, Contexto.

Datafolha Instituto de Pesquisas (2015): 47\% foram à Avenida Paulista em 15 de março protestar contra a corrupção. 15 de marzo de 2015. http:// datafolha.folha.uol.com.br/opiniaopublica/2015/03/1604284-47-foram-aavenida-paulista-em-15-de-marco-protestar-contra-a-corrupcao.shtml. Acceso el 14 de septiembre de 2015.

Fundaçao Perseu Abramo (2015): Projeto Manifestações de marzo 2015. http://novo.fpabramo.org.br/sites/default/files/fpa-pesquisa-manifestacoes.pdf. Acceso el 14 de septiembre de 2015.

GoFFMAN, E. (2012): Estigma: notas sobre a manipulação da identidade deteriorada, Rio de Janeiro, LTC.

Guimarães, L. (2000): A cor como informação: a construção biofísica, linguística e cultural da simbologia das cores, São Paulo, Annablume.

- (2003): As cores na mídia: a organização da cor-informação no jornalismo, São Paulo, Annablume.

V An Disk, T. A. (2015 a): Antirracismo e discurso político no Brasil. Palestra realizada en la IV Jornada de Estudos de Linguagem, 9 septiembre 2015, Niterói, Brasil.

- (2015 b): «Discurso das elites e racismo institucional» en Proença, G.; R. Pacheco (orgs.). Discurso e (des) igualidade social, São Paulo, Contexto, 31-48. 